\title{
Monitoring saltwater intrusion in Rupert Bay, Québec, Canada, after the partial diversion of a major tributary
}

\author{
Vincent Métivier • Bernard Massicotte • \\ Alain Tremblay • Pierre Dupuis
}

Received: 12 January 2017 / Accepted: 5 December 2017 /Published online: 21 December 2017

(C) The Author(s) 2017. This article is an open access publication

\begin{abstract}
As part of a large hydroelectric project in northern Québec (Canada), a portion of the flow of the Rupert River was diverted toward the existing La Grande hydroelectric complex. As a result of the partial diversion, the discharge of the Rupert River at its mouth is reduced by an average of $50 \%$ annually. This corresponds to an $18 \%$ decrease in the total freshwater inflow into the bay and, thus, to a shift of the upstream limit of the saltwater intrusion in Rupert Bay. Changes in saltwater intrusion had been predicted numerically as part of the project's environmental impact assessment (EIA). In the project's conditions of authorization, monitoring the hydraulic conditions and the extent of saltwater intrusion in the Rupert Bay was required by government authorities. The objective of this paper is to present the results of this environmental monitoring and, more specifically, to validate the modifications predicted in the EIA in terms of both saltwater intrusion limit and
\end{abstract}

\footnotetext{
V. Métivier $(\bowtie)$

Energy Unit, WSP Canada, Québec City, QC, Canada

e-mail: Vincent.Metivier@wsp.com
}

B. Massicotte

Environmental Unit, WSP Canada, Québec City, QC, Canada

e-mail: Bernard.Massicotte@wsp.com

A. Tremblay

Hydro-Québec, Montréal, QC, Canada

e-mail: tremblay.alain@hydro.qc.ca

P. Dupuis

Energy Unit, WSP Canada, Laval, QC, Canada

e-mail: Pierre.Dupuis@wsp.com hydraulic conditions in the Rupert Bay. Results obtained during 2 years of monitoring are within the predicted trends and order of magnitude of changes anticipated in the EIA. The results, thus, confirm that the shift of the upstream limit of the saltwater front along the channels of the bay was conservatively predicted by numerical modeling.

Keywords Saltwater intrusion · Monitoring $\cdot$ River diversion · Ice cover

\section{Introduction}

Lakes, rivers, and estuaries as well as wetlands and forests are part of the Earth's freshwater cycle. Generally, in Quebec, the largest river runoffs take place from April to June as snow melts in spring, the smallest runoffs occurring during winter. It is well-known that the creation of reservoir either for water management (irrigation, flood control, etc.) or for energy generation (reservoir, pump station) can have a significant effect on the river hydrological cycle by changing this general pattern (Prinsenberg, 1994, Rosenberg et al., 2000). Canadian winters correspond to high electricity demand that results in the release of a large amount of freshwater to the estuary that may have implications for plume surface area as well as estuarine dynamics (Dunbar, 1982; Messier and Anctil, 1996, Hayeur, 2001).

The Connecticut River (Garvine, 1974, 1975, 1977), La Grande Rivière, Great Whale River (e.g., Ingram and Larouche, 1987a, Prinsenberg 1994), and Fraser River 
(Cordes et al. 1980) are some examples of studied river plumes. In river systems where the ratio of mean freshwater discharge velocity to tidal current at the river's mouth is large, extensive plumes are formed at all times of the year (Prinsenberg 1982, 1994). Plumes are also present during winter and early spring, when runoff values are at their smallest levels (Ingram, 1981). For ice-free periods, Garvine (1975) showed that the surface area of the Connecticut River plume varied in an approximately linear manner with volume of discharged freshwater. Similarly, with 42 river discharge data from 1966 to 1994, Déry et al. (2005) suggested a relationship between freshwater discharge and salinity. They suggested that a gradual salinization of the upper ocean during summer over the period of 1966-1994 on the inner Newfoundland Shelf is in accord with a decadal trend of a diminishing intensity in the continental meltwater pulses. Plumes are also affected by tidal amplitude and costal circulation as observed by Cordes et al. (1980) in the Fraser estuary and by Ingram and Larouche (1987a) in Hudson Bay. Wind is another parameter known to influence dynamics and flushing rates of shallow estuaries as reported by Geyer (1997).

Knowledge of under-ice plumes is fairly recent. Most of the studies were undertaken on the east coast of the James and Hudson Bays, motivated by the development of hydroelectric potential of northern Quebec. In that regard, Freeman (1982), Ingram (1981), and Ingram and Larouche (1987a) on Great Whale River as well as Messier et al. (1986, 1989) and Ingram and Larouche (1987b) on La Grande Rivière have shown that there is a marked increase in plume area for a given freshwater discharge under sea ice compared to open-water conditions.

The main justifications invoked to explain the vertical and horizontal extents of the winter plumes are the suppression of wind mixing and attenuation of tidal mixing (Ingram 1981, 1983; Freeman et al. 1982, Lepage and Ingram, 1991) reducing the overall energy available for mixing, which results in a much more stable interface between fresh and ambient water masses.

As part of the Eastmain-1-A, Sarcelle, and Rupert diversion project that was commissioned in 2009 by Hydro-Québec, a portion of the Rupert River water flow was diverted to the Eastmain 1 reservoir, through a series of diversion canals and tunnels. The discharge of the Rupert River at its mouth into Rupert Bay is thus reduced to an average of $50 \%$ annually. The potential impacts of this hydrological change have been the subject of specific studies conducted as part of the Eastmain-1-A-Sarcelle-Rupert project's environmental impact assessment (EIA) (Hydro-Québec, 2004). As part of this study, 2D hydraulic modeling was conducted to predict the effect of the diversion on the intrusion of saltwater within Rupert Bay. The hydrodynamic model Mike $21 \mathrm{HD}^{\mathrm{TM}}$, from the Danish Hydraulic Institute (DHI), was used to describe the hydrodynamic regime of the Rupert Bay (Dupuis, 2004). The numerical model predicted a displacement of the maximum intrusion of the saline front $5 \mathrm{~km}$ upstream within Rupert Bay and no noticeable variation in water levels in the bay (Dupuis, 2004; Hydro-Québec, 2004). Furthermore, a slight shift of the freshwater flow corridors from the Nottaway, Rupert, and Broadback Rivers in Rupert Bay toward the northeast was predicted (Hydro-Québec, 2004). Predictions provided insights into physical processes and assessed impacts of diversion of a major tributary of the Rupert Bay. Few years after the diversion of the Rupert River, one could ask the following:

1) How does the limit of saline intrusion differ from the post-diversion baseline, in both ice-free and ice cover conditions?

2) How do the changes predicted in the EIA compare to post-diversion measurements?

Monitoring of saltwater intrusion in post-diversion conditions was undertaken in 2010 and 2013 to answer these questions. The objective of this paper is to present the results of this environmental follow-up, more specifically, to validate the modifications predicted in the EIA in terms of both saltwater intrusion limit and hydraulic conditions (water levels) in the Rupert Bay in both ice-free and ice cover conditions.

With the increasing pressure exerted on freshwater resources, it is more than ever important to improve the methodology and the empirical knowledge of the effects of river diversions. This paper will hopefully benefit researchers and environmental managers interested in the prediction and validation of the effects of river diversions on oceanographic processes.

\section{Study area}

The Rupert Bay is in the boreal ecoregion of Québec, Canada, about $800 \mathrm{~km}$ north of Montréal. The watershed is dominated by coniferous forest and shallow 
podzolic and peat soils developed over igneous bedrock and quaternary sediments. Aquatic systems are described as oligotrophic - characterized by a low water nutrient concentration and a high oxygen content. The hydrology of the Rupert Bay watershed $\left(139,465 \mathrm{~km}^{2}\right.$ in natural conditions (Hydro-Québec, 2004)) reflects the regional climate; runoff is strongly seasonal, with high flows in the spring (peaking in May or June) and low flows in late winter.

Rupert Bay is a shallow (3-5 m), turbid river estuary located off the southeast of James Bay (Fig. 1). It can be divided into three zones: freshwater, brackish water, and saltwater zones. In the freshwater zone, it received a mean annual freshwater inflow varying from 1000 to more than $7000 \mathrm{~m}^{3} \mathrm{~s}^{-1}$ from four major tributaries, the Nottaway, Broadback, Rupert, and Pontax Rivers (Figs. 1 and 2). The decrease in the Rupert's discharge, following the diversion, corresponds to an $18 \%$ decrease in the total freshwater inflow to the bay. To reduce the impact of the project on the Rupert and Lemare Rivers, eight weirs were built on the Rupert River to maintain the water level for different uses of the river such as navigation and fish spawning areas, and an ecological instream flow that reproduces the natural hydrological cycle on both rivers is maintained.

Characterization of freshwater inflows is required as it plays a significant role in the saltwater intrusion pattern found over Rupert Bay. The combination of shallow depths, bay dimension, and large quantities of freshwater inflows creates zones of fresh and brackish waters within the bay. The saltwater boundary moves upstream and downstream under the influence of tidal forcing and freshwater inflow that comes mainly from the Nottaway, Broadback, Rupert, and Pontax Rivers.

Prior to the 2009 diversion, the smallest freshwater inflow occurred late in winter and was in the order of 1000 to $2000 \mathrm{~m}^{3} \mathrm{~s}^{-1}$. In summer, smallest inflows ranged between 2000 and $5000 \mathrm{~m}^{3} \mathrm{~s}^{-1}$ (Fig. 2). For the same periods, post-diversion inflows vary in the order of 900 to $1500 \mathrm{~m}^{3} \mathrm{~s}^{-1}$ in winter and fluctuate between 1000 and $2000 \mathrm{~m}^{3} \mathrm{~s}^{-1}$ in summer. In the period of spring freshet, total river discharges ranged from 2700 to $7500 \mathrm{~m}^{3} \mathrm{~s}^{-1}$ (preand post-diversion 2008-2013).

In 2013, freshwater discharge from the four main tributaries ranged between 786 and $6272 \mathrm{~m}^{3} \mathrm{~s}^{-1}$ (Consortium Waska-Genivar, 2014). Spring freshet spanned the months of May and June. Between February 10th and April 3rd, the mean total freshwater inflow was $933 \mathrm{~m}^{3} \mathrm{~s}^{-1}$. It ramped up to $1746 \mathrm{~m}^{3} \mathrm{~s}^{-1}$ between July 22nd and August 26th. Despite the diversion, freshwater inflows in Rupert Bay were larger in 2013 than in 2010, especially during the freshet and in summer. With respect to the winter period, a comparison of freshwater inflows shows that the total discharge evaluated in 2013 was slightly larger than in 2010 . This analysis shows that 2010 was not a typical post-diversion year, the incoming flow being much smaller in 2010 than those evaluated for the previous 2 years.

In post-diversion conditions, freshwater inflows are found to be less for the periods of FebruaryMarch and July-August than those of pre-diversion conditions. From January 1st to mid-March 2010 as well as June to September 2010, the total inflow was below the lower envelope curve of inflow for the period of pre-diversion. Furthermore, reconstituted freshwater inflows for conditions without diversion show that for 2010, flows were also below this curve for the months of January, June, July, and August. Low freshwater inflow in Rupert Bay is related to a low runoff for this year. Owing to the relatively large volume of the bay, these smaller freshwater inputs had no discernible effect on the water level as will be shown hereafter.

The mean annual air temperature is in the order of 0.5 to $3{ }^{\circ} \mathrm{C}$ and varies between $-33{ }^{\circ} \mathrm{C}$ in the winter and $31{ }^{\circ} \mathrm{C}$ in the summer. Atmospheric pressure varies generally between 97.9 to $103.4 \mathrm{kPa}$ with westerly winds dominating with speeds from 5 to $40 \mathrm{~km} / \mathrm{h}$, and wind peaks ranged from 60 to $80 \mathrm{~km} / \mathrm{h}$ but can go up to $100 \mathrm{~km} / \mathrm{h}$ for short periods of time (Consortium Waska-Genivar, 2014).

Semidiurnal tides play a significant role in the water level variations of the bay (Consortium Waska-Genivar, 2014). In open water, water levels generally vary between -1 and $1 \mathrm{~m}$ (MSL), while under an ice cover, they generally range between 0.5 and $0.5 \mathrm{~m}$ (MSL) (Environnement Illimité INC, 2011, Consortium Waska-Genivar, 2014). Water level variations in Rupert Bay are also influenced by weather conditions. For example, on August 22nd, 2003, water levels of up to $4 \mathrm{~m}$ (MSL) were observed when northwest winds exceeding $100 \mathrm{~km} / \mathrm{h}$ and atmospheric pressure below $99 \mathrm{kPa}$ were measured (Dupuis, 2004). 


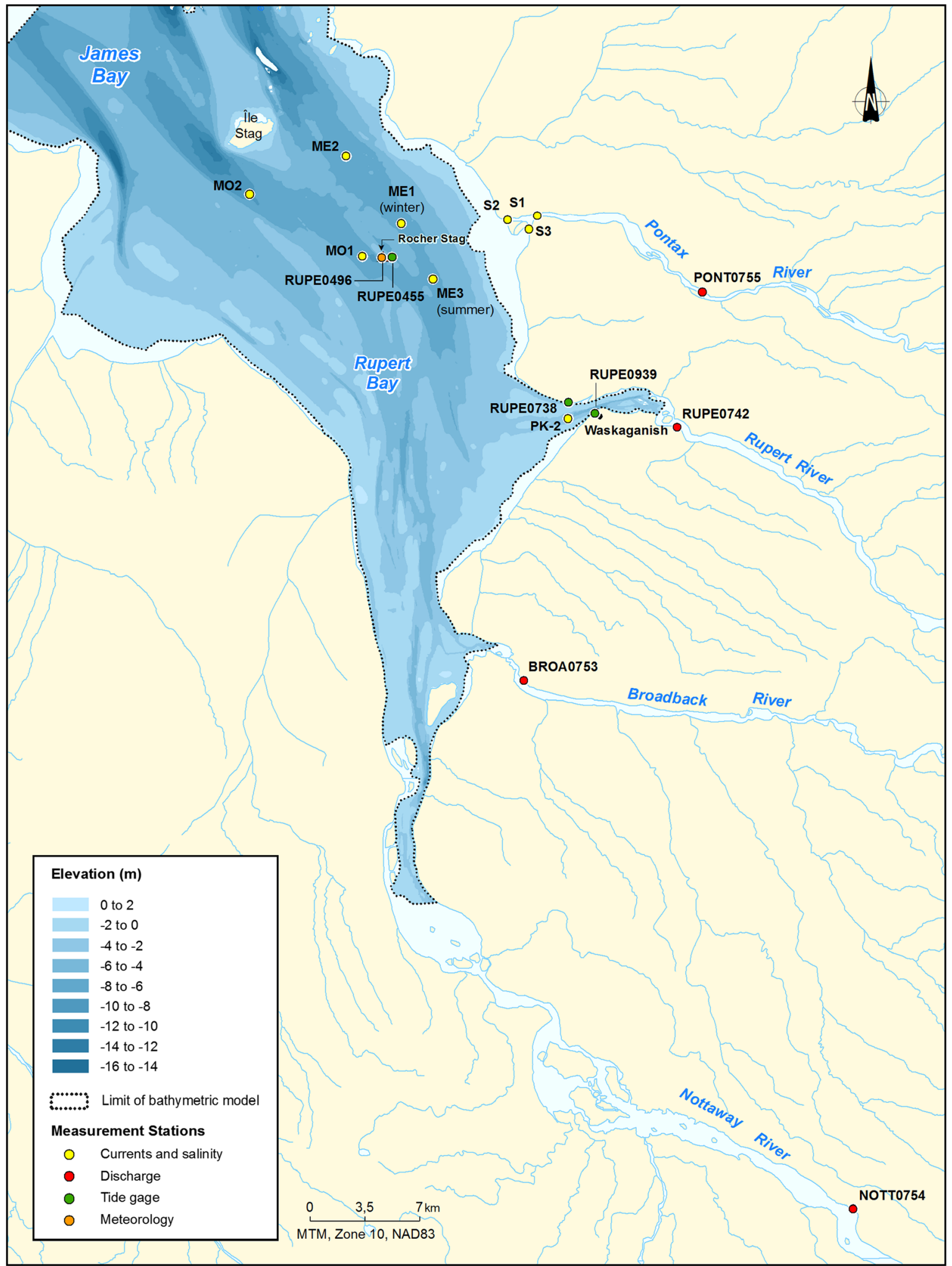

Fig. 1 Location of data-logging stations 


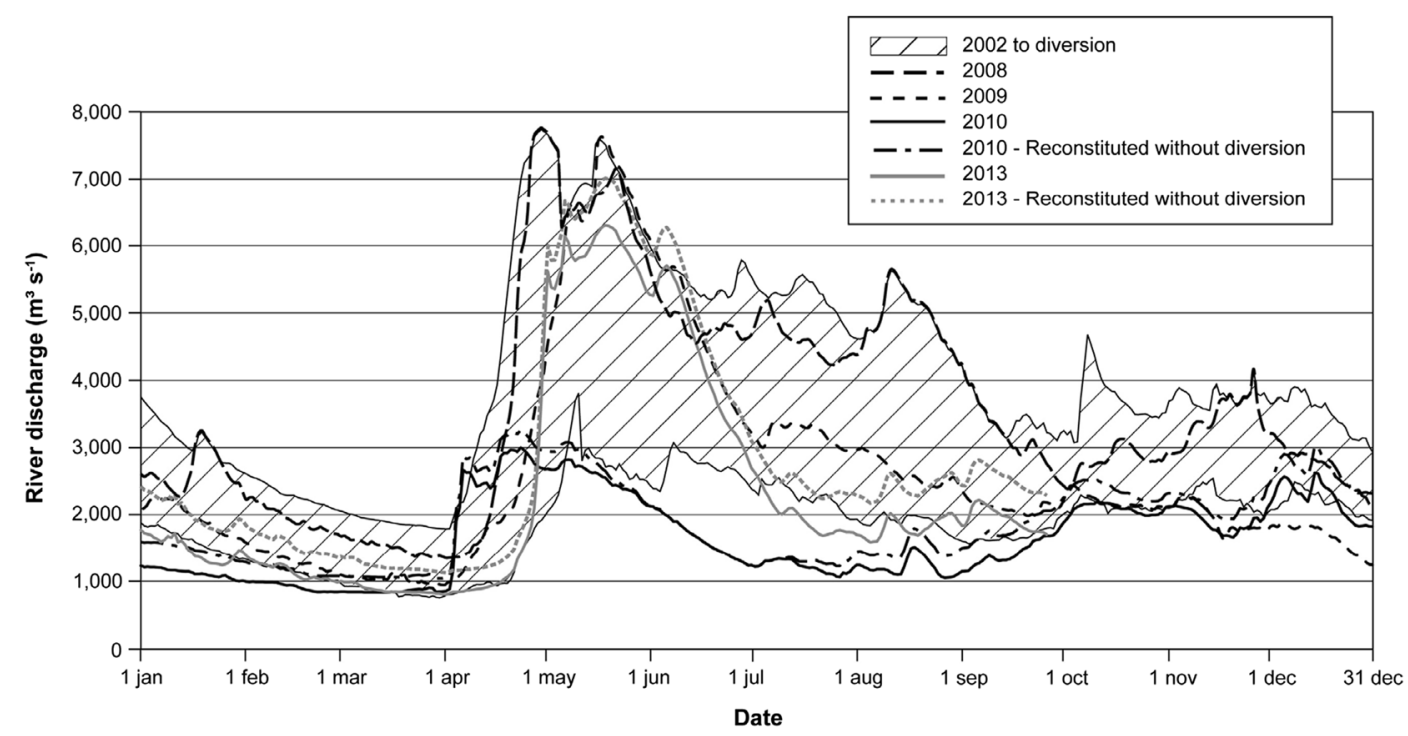

Fig. 2 Daily total and reconstituted discharges in Rupert Bay (daily total discharge from Nottaway, Broadback, Rupert, and Pontax rivers) during 2008, 2009, 2010, and 2013 without diversion

\section{Materials and methods}

The effect of the Rupert diversion on the intrusion of saltwater was assessed as part of a larger program aiming to understand the environmental effects of the Rupert River diversion. Hydro-Québec has been operating weather, water level, and limnimetric stations in Rupert Bay (Fig. 1), for over 10 years, thus both before and after the diversion, which occurred in November 2009. The data records from these stations that were used in the present study are indicated in Table 1.

Salinity data, on the other hand, are not regularly collected in Rupert Bay. The salinity data used in this study stem from data collection programs, which were conducted prior to the diversion, in 2003, and after the diversion, in 2010 and 2013, as part of the present study.

For post-diversion conditions, a monitoring protocol was developed in 2007 and oceanographic moorings and field campaigns were conducted both in the winters and summers of 2010 and 2013. The data from these campaigns, unpublished yet, were collected specifically for the purpose of this study. ${ }^{1}$ The measurements were made during periods when saltwater intrusion is expected to be the greatest, with the goal of capturing the maximum intrusion of the front. For both postdiversion years, measurements were made at the end

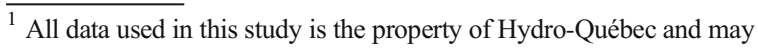
be obtained by a request to A. Tremblay.
}

of winter and summer, the two periods of the year when freshwater discharge into the bay is the smallest. Also, the four salinity and current measurement campaigns were carried out during a spring tide, when the inflow of saltwater into the bay is, in theory, greater. The data collected in post-diversion conditions for the purpose of this study are detailed in the following sections.

\section{Rupert Bay}

The measurements in Rupert Bay included continuous recordings at four mooring stations as well as discrete measurements along the main channels and the shores. Two mooring stations were installed along the west channel and two along the east channel (Fig. 1). Each mooring station included a subsurface and bottom CTD (conductivity, temperature, and depth) sonde (RBR Concerto) and an acoustic Doppler current profiler (ADCP Sentinel Workhorse 600 and $1200 \mathrm{kHz}$ ). The moorings were deployed for periods ranging from 35 to 49 days comprising two spring tides.

During each of the four post-diversion campaigns, two or three mobile teams simultaneously made discrete measures at specific stages of the tidal cycle to locate the maximum extension and retreat of the saline front. The measures consisted in CTD profiles using RBR XR-420 and RBR XR- 
Table 1 Summary of the data used to compare the saltwater intrusion in Rupert Bay in pre- and post-diversion conditions

\begin{tabular}{|c|c|c|c|c|c|}
\hline Data & Data logging frequency & Data averaging & $\begin{array}{l}\text { Pre-diversion (natural } \\
\text { conditions) }\end{array}$ & Post-diversion year 1 & $\begin{array}{l}\text { Post-diversion } \\
\text { year } 4\end{array}$ \\
\hline Air temperature & $15 \mathrm{~min}$ & Hourly & \multirow[t]{5}{*}{ Jan. 2008-Nov. 2009} & \multirow[t]{5}{*}{ Nov. 2009-Dec. 2010} & \multirow[t]{5}{*}{ Jan.-Oct. 2013} \\
\hline $\begin{array}{l}\text { Atmospheric } \\
\text { pressure }\end{array}$ & $15 \mathrm{~min}$ & Hourly & & & \\
\hline $\begin{array}{l}\text { Wind velocity } \\
\text { and direction }\end{array}$ & 15 to $60 \mathrm{~min}$ & Hourly & & & \\
\hline $\begin{array}{l}\text { Freshwater } \\
\text { discharge }\end{array}$ & Daily & None & & & \\
\hline Water levels & 15 to $60 \mathrm{~min}$ & Hourly & & & \\
\hline Salinity & $\begin{array}{l}1 \text { min for moorings; } \\
<10 \mathrm{~s} \text { for discrete } \\
\text { measurements and } \\
\text { manual measurements }\end{array}$ & $\begin{array}{l}\text { No temporal } \\
\text { averaging for } \\
\text { moorings; water } \\
\text { column averaging for } \\
\text { discrete measurements }\end{array}$ & Mar. 2003 & Feb.-Apr. 2010 & $\begin{array}{c}\text { Feb.-April } \\
2013\end{array}$ \\
\hline $\begin{array}{l}\text { Current velocity } \\
\text { and direction }\end{array}$ & 10 to $15 \mathrm{~min}$ & Hourly & Aug.-Sept. 2003 & Aug.-Sept. 2010 & Jul.-Aug. 2013 \\
\hline
\end{tabular}

620 loggers, additional salinity measurements (YSI 556 and YSI Professional Plus multisondes), and current velocities (Rio Grande Workhorse 600 and $1200 \mathrm{kHz}$ ADCPs). The measures were made along the channels during each campaign and also along the shores during the summer campaigns. Table 2 shows the number of vertical salinity profiles conducted in pre- and post-diversion conditions. In order to follow the salinity front during the tide cycles over distances of kilometers, the teams used helicopters during winter and summer campaigns as well as boats during the summer campaign (Fig. 3).

The bottom depth in the surveyed area was generally between 3 and $7 \mathrm{~m}$. For the sake of locating the saltwater front, the water column was thus considered as well-mixed. In this study, the saltwater front is defined by a salinity of 0.5 averaged over the water column.

Table 2 Number of vertical salinity profiles conducted to locate the saltwater front in Rupert Bay, in pre- and post-diversion conditions

\begin{tabular}{llll}
\hline Period & Pre-diversion & \multicolumn{2}{l}{ Post-diversion } \\
\cline { 3 - 4 } & 2003 & 2010 & 2013 \\
\hline Winter (ice cover) & N/A & 223 & 164 \\
Summer (open water) & 220 & 230 & 544 \\
\hline
\end{tabular}

\section{Mouth of the Pontax River}

The saltwater intrusion was also monitored at the mouth of the Pontax River, a tributary of Rupert Bay. One multiparameter sonde (InterOcean System S4) was moored upstream from the mouth and two more in the main channels downstream from the mouth (Fig. 1). The sondes were mounted on a rack and moored on the sea floor. The variables monitored were salinity and current velocity and direction.

Weather, freshwater discharge, and tidal data

Data on air temperature, atmospheric pressure, and wind velocity and direction were obtained from a weather station located on Stag Rock (Fig. 1), operated by Hydro-Québec. Additional data on air temperature and atmospheric pressure from the nearby Waskaganish weather station were used where gaps existed in the Stag Rock data.

Freshwater discharge data were obtained from the gauging stations operated by Hydro-Québec in the main tributaries of Rupert Bay, i.e., the Nottaway, Broadback, Rupert, and Pontax Rivers, for the pre- and postdiversion periods.

Water level data for both periods were obtained from the Stag Rock station and from two stations located at the mouth and $2 \mathrm{~km}$ upstream from the mouth of the Rupert River. 
Fig. 3 Locating the saltwater front near the shore

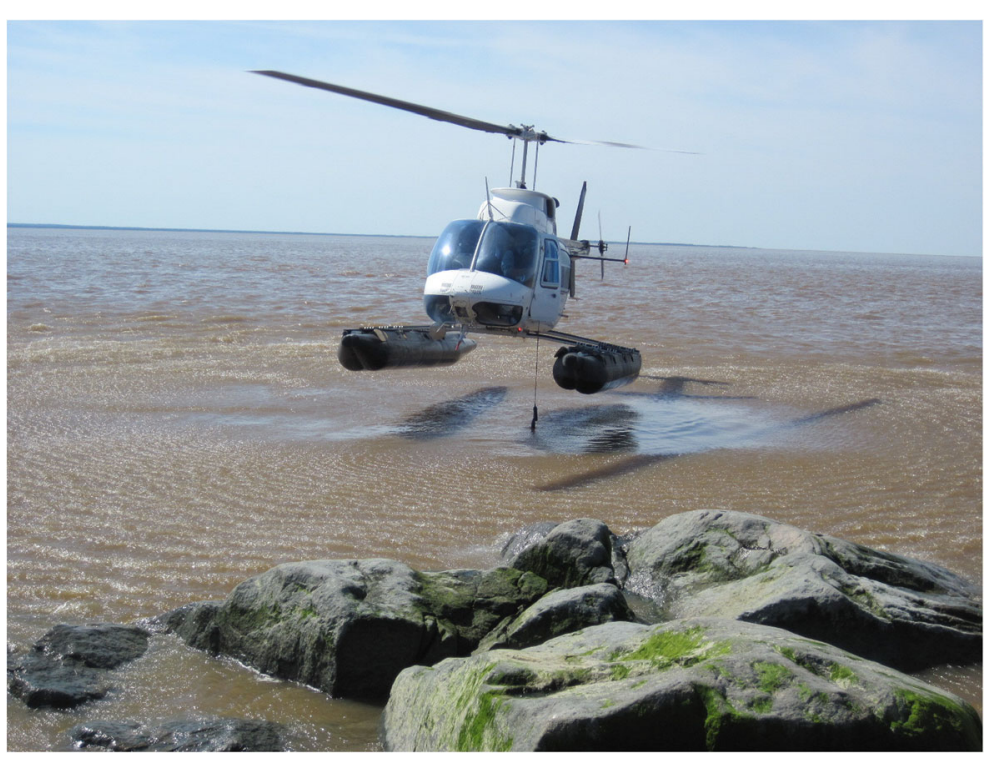

Data analysis

The time series of weather, river discharge, water level, and salinity data was examined for gaps and outliers. Figure 4 presents an example of water level, salinity, and current time series. Short periods of missing data (e.g., less than a tidal cycle or $5 \mathrm{~h}$ ) were completed using linear interpolation. Longer data gaps were completed by transposition of the data recorded at a nearby station.

Water levels in the Rupert Bay were examined using a cumulative sum method (Dupuis 2010) to detect any vertical translation of the sensors. Interannual variations of the main tidal constituents were analyzed using tidal harmonic analysis. Sixty harmonic components of the tidal cycle were assessed using the Aquawave software (GENIVAR, 2011, implementation in C++ of Foreman development (1977)) for a time series of 35 days or more. To assess the effect of meteorological disturbances on water levels, a low-pass filter $\left(\mathrm{A}_{24} \mathrm{~A}_{24} \mathrm{~A}_{25}\right.$, Godin 1972) was applied to the series in order to remove the tidal signal. Pre- and post-diversion conditions were compared using water level duration curves, using hourly data from the RUPE0455, RUPE0738, and RUPE0939 stations. It was shown that the discharge data at station RUPE0738 is biased due to location and ice effects that alter the flow when an ice cover is present (Dupuis 2010, Environnement Illimité INC, 2011); thus, this station was used for ice-free periods only.

\section{Results}

Saltwater intrusion

Discrete salinity data were used to evaluate the limits of saline intrusion. During the summer of 2013 campaign, the upstream location where salinity reached 0.5 was located approximately 5 to $6 \mathrm{~km}$ upstream of Stag Rock in both channels of the Rupert Bay and on the east shore (Fig. 5). On the west shore, the upstream intrusion limit was located more than $10 \mathrm{~km}$ upstream of Stag Rock. Under ice cover conditions, the limits of saline intrusion were located downstream compared to open-water conditions. Salinity reached 0.5 approximately $7 \mathrm{~km}$ downstream of Stag Rock in the west channel and $5 \mathrm{~km}$ in the east channel (Fig. 6).

A comparison of pre- and post-diversion conditions shows a saltwater intrusion limit that reaches further upstream of Stag Rock due to a smaller total freshwater inflow (Fig. 7). Since freshwater discharge during monitoring averaged $2971 \mathrm{~m}^{3} \mathrm{~s}^{-1}$ in $2003,1226 \mathrm{~m}^{3} \mathrm{~s}^{-1}$ in 2010, and 1746 in 2013, the discharge rates during low water of 2010 and 2013 were smaller by 60 and $40 \%$ when compared to those of 2003. Before diversion, the limit of saltwater intrusion in the channels was located a few kilometers upstream of Stag Rock, in front of the mouth of the Pontax River. In post-diversion conditions, intrusion moved upstream by 4 to $6 \mathrm{~km}$ along the main channels. Onshore, intrusion also appears to have 

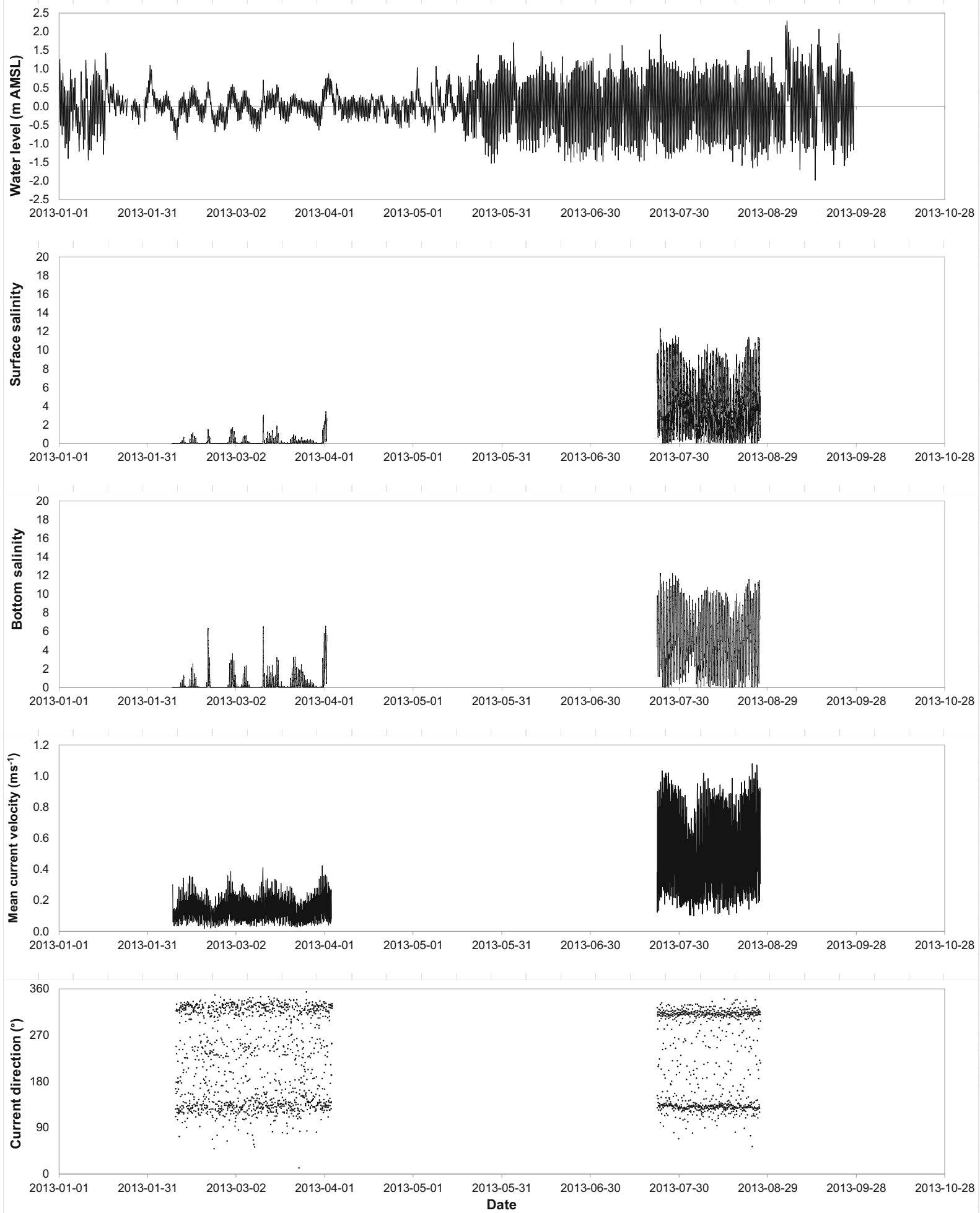

Fig. 4 Time series of the water level at Stag Rock (RUPE0455), surface and bottom salinities, and current velocity and direction at station $\mathrm{MO} 2$ 
Fig. 5 Salinity as a function of distance from Stag Rock (positive in the downstream direction) in open-water conditions during the 2013 monitoring. Yellow dashed line: intrusion of the saline front. Purple dashed line: retreat of the saline front

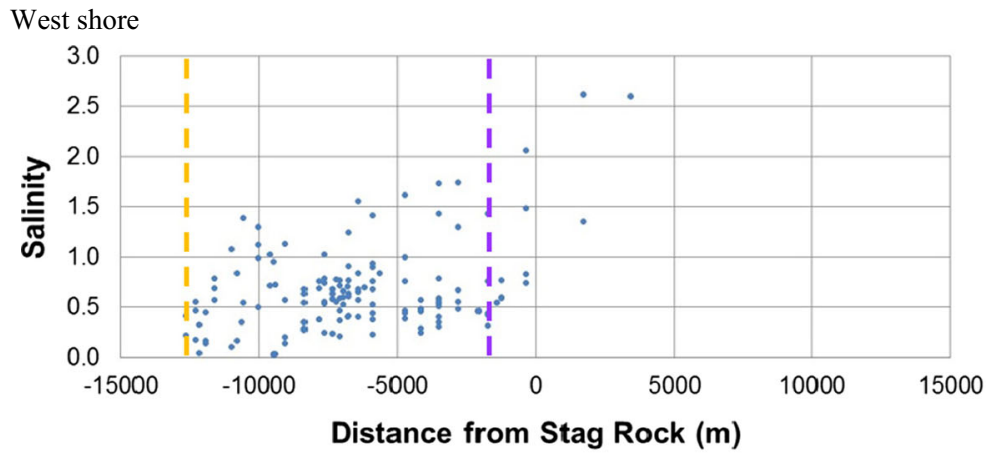

West channel

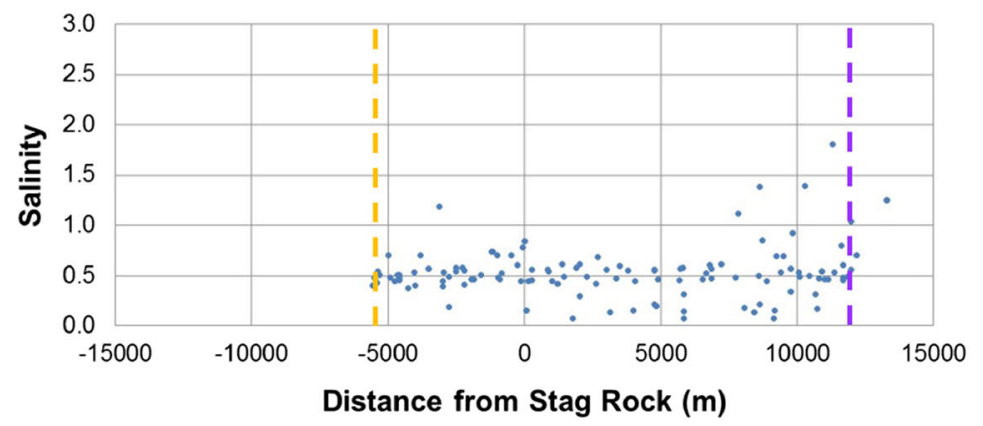

East channel

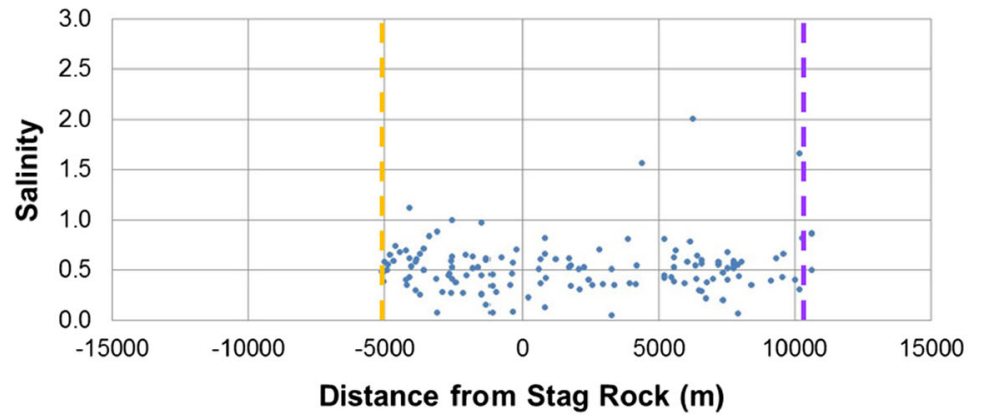

East shore

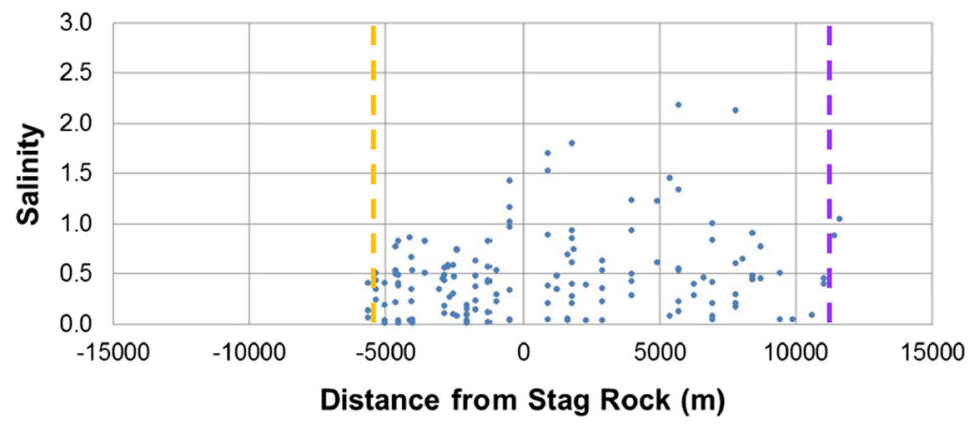

increased, especially on the eastern shore of the bay. In 2003, the upstream boundary of the intrusion on the east bank of the bay was located near the edge of the Bois Brule Point (Fig. 8). In 2013, it reached the mouth of the Pontax River, approximately $8 \mathrm{~km}$ upstream. As for the west bank, the limit reached the downstream sector of the Octave River in 2003 and 2010, while in 2013, the intrusion progressed approximately $6 \mathrm{~km}$ further upstream toward the mouth of the Rupert Bay. 
Fig. 6 Salinity as a function of distance (positive in the downstream direction) from Stag Rock in ice cover conditions during the 2013 monitoring. Yellow dashed line: intrusion of the saline front. Purple dashed line: retreat of the saline front

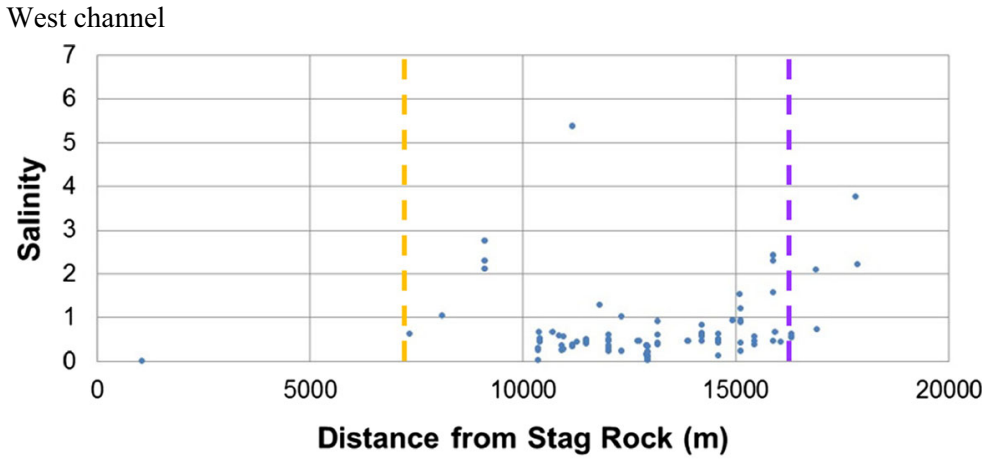

East channel

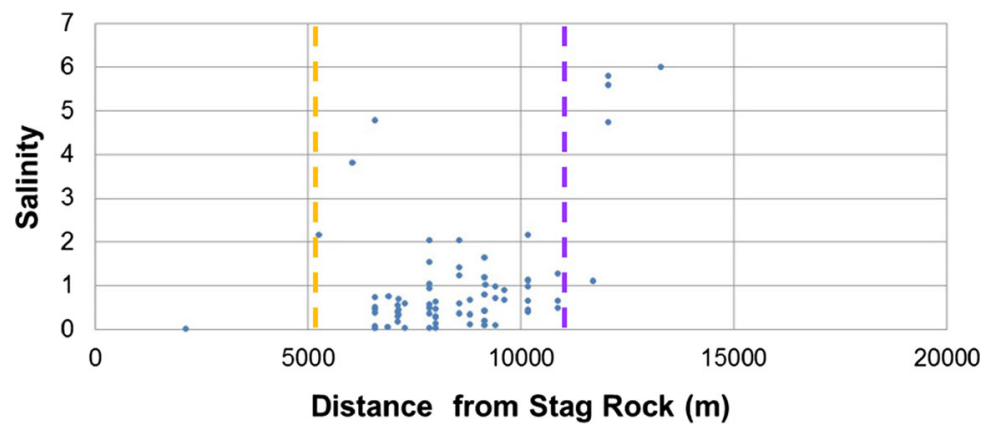

Under ice cover conditions, the limit of saltwater intrusion has not reached Stag Rock Island for all years of monitoring (2003, 2010, and 2013; Fig. 8), while in open water, it went a few kilometers upstream. This phenomenon is explained by the additional friction caused by the presence of the ice cover which obstructs the water flow and lowers the tidal amplitude. Thus, in winter, saltwater intrusion in Rupert Bay mainly depends on the tide and weather disturbances that significantly affect water levels in the bay. Freshwater inflows in Rupert Bay in 2013 (average of $933 \mathrm{~m}^{3} \mathrm{~s}^{-1}$ ) are slightly larger than those during previous monitoring years (from 790 to $845 \mathrm{~m}^{3} \mathrm{~s}^{-1}$ ). Differences in the location of intrusion and retreat of the saline front are mainly related to changes induced by weather fluctuations and the state of the ice cover that prevailed during the limited time span of the field campaign for tracking the movement of the saline front.

Water levels

Non-exceedance curves show that for all years of observation (Fig. 9), the water surface elevation near Stag Rock oscillates between -1.0 and $1.0 \mathrm{~m}$ about $80 \%$ of the time. Despite the smaller freshwater inflow for all the rivers in 2010, non-exceedance curves during 2010 and 2013 show similar responses, with only slight differences for extreme water level events. Weather conditions such as wind velocity and atmospheric pressure are likely responsible for these differences. A comparison between non-exceedance stage curves for pre- and postdiversion conditions shows that there is no significant effect of the diversion on the water levels in the Rupert Bay.

Under ice cover conditions, non-exceedance curves show that for all years (Fig. 10), water levels fluctuate between -0.5 and $0.5 \mathrm{~m}$ about $80 \%$ of the time. Compared to open-water conditions, the presence of ice cover causes larger interannual variations. Non-exceedance curves for years 2010 and 2013 show discrepancies, especially for extreme values. These differences can be explained by differences in weather conditions and by the variability in the time period needed to develop the ice cover over the entire bay area. For non-exceedance percentages above $10 \%$ and below $90 \%$, interannual differences in water levels were small despite a difference of more than $40 \%$ of freshwater discharge into Rupert Bay for periods under ice cover between 2008 and 2010 (see Fig. 2). Finally, despite the 


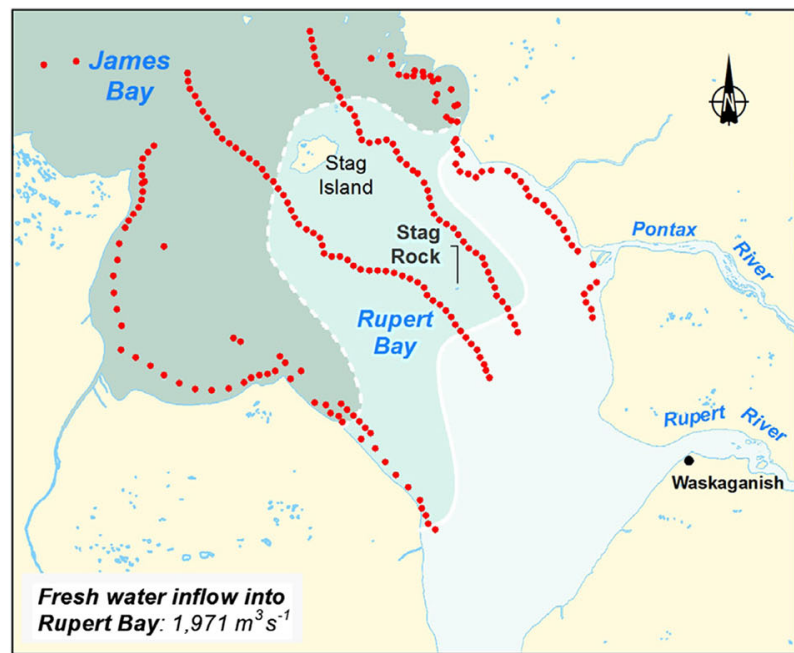

2003 - Reference conditions Spring tide

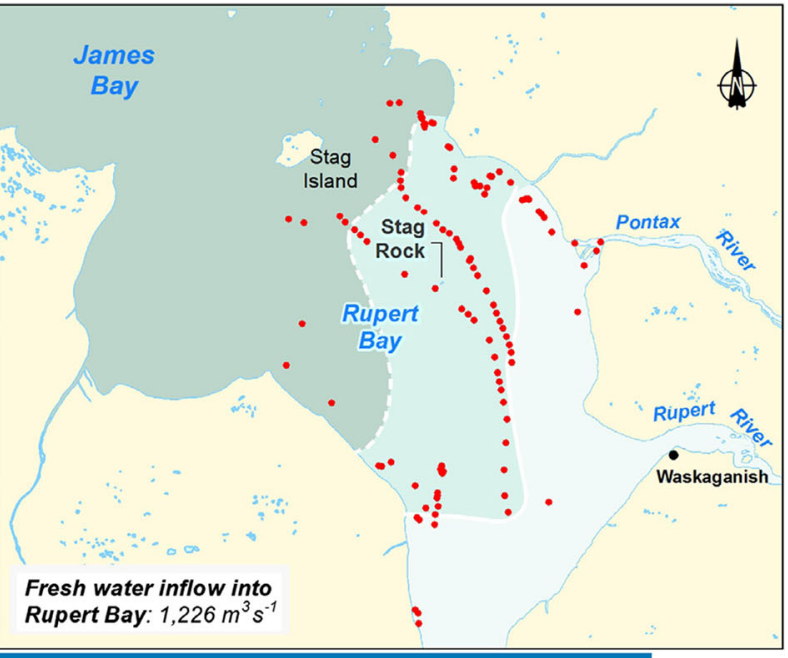

2010 - Post-diversion conditions Spring tide
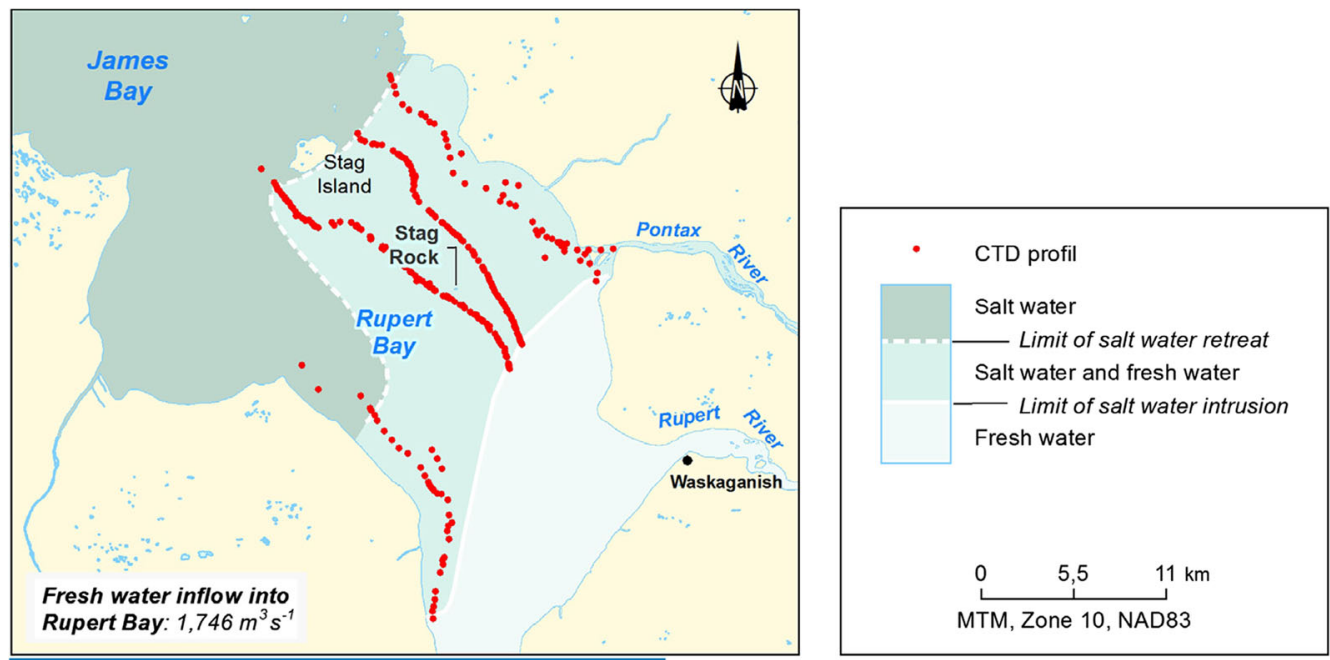

2013 - Post-diversion conditions Spring tide

Fig. 7 Limits of saltwater intrusion and retreat before and after diversion in open-water conditions

yearly differences in freshwater inflows, there is no difference for the median water level.

In post-diversion conditions, water levels measured in the estuary of the Rupert River at station RUPE0939 are lower than those measured in pre-diversion conditions (Fig. 11, close to Waskaganish village). The $10-\mathrm{cm}$ decrease in the mean water level is explained by a decrease in the mean river discharge. River-like response at low tide reveals the influence of the diversion on the water levels in the estuary. The decrease reached $30 \mathrm{~cm}$ for extreme low water at station RUPE0939 for the time period of analysis.
In winter, the tidal range in the bay and in the estuary of the Rupert River is much smaller, again because of the presence of ice cover. Nonexceedance curves for the years 2009, 2010, and 2013 show that water levels are below $1 \mathrm{~m}$ more than $95 \%$ of the time (Fig. 12). For 2010 and 2013, curves show a similar behavior; however, water levels in 2013 were slightly lower than those measured in 2010. The most plausible explanation for the fact that the mean water level is larger in 2010 compared to that in 2013 lies in the different conditions of ice cover and different ice characteristic conditions. 


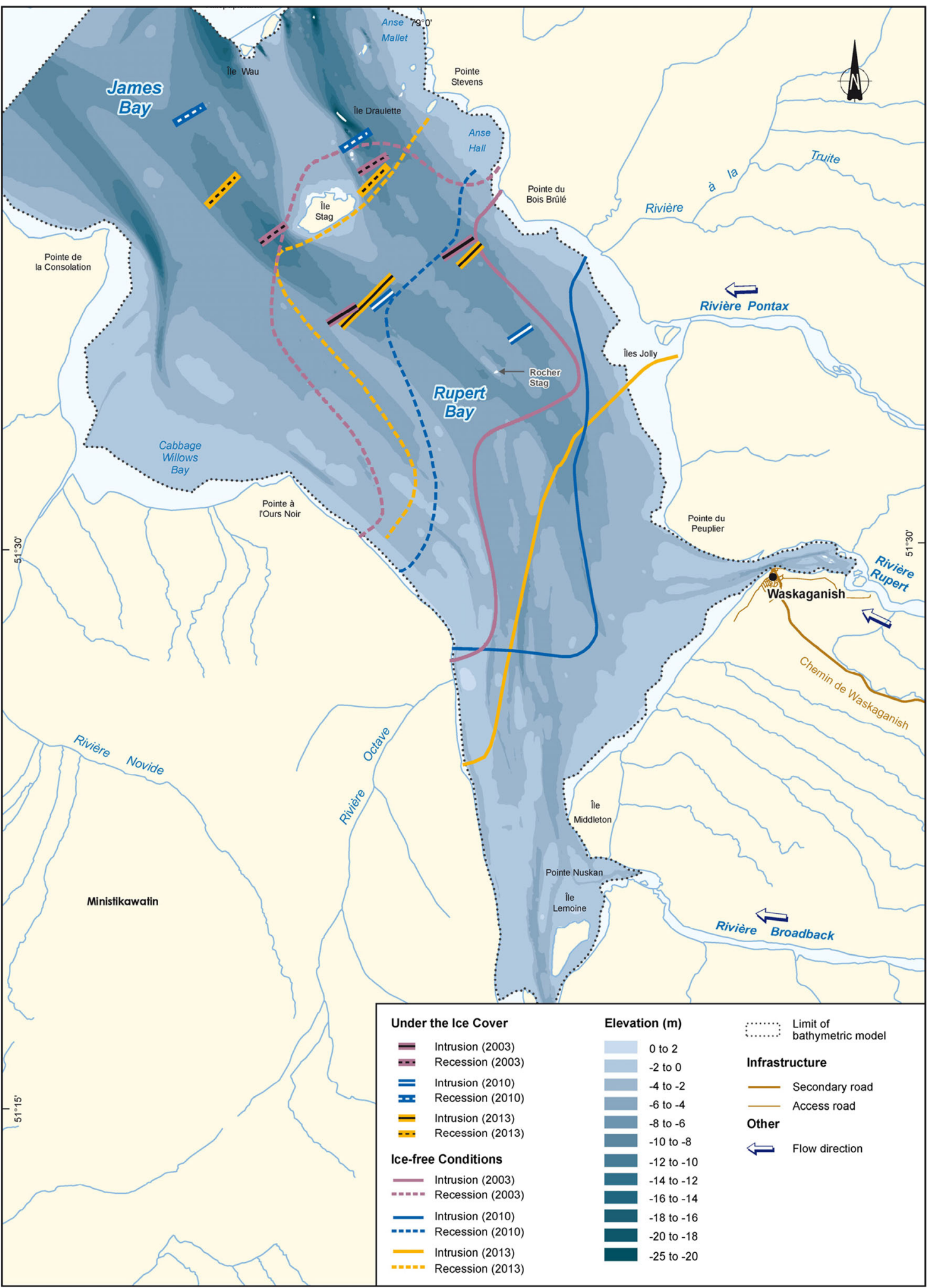

Fig. 8 Measured limits of saltwater intrusion in open-water and ice cover conditions 


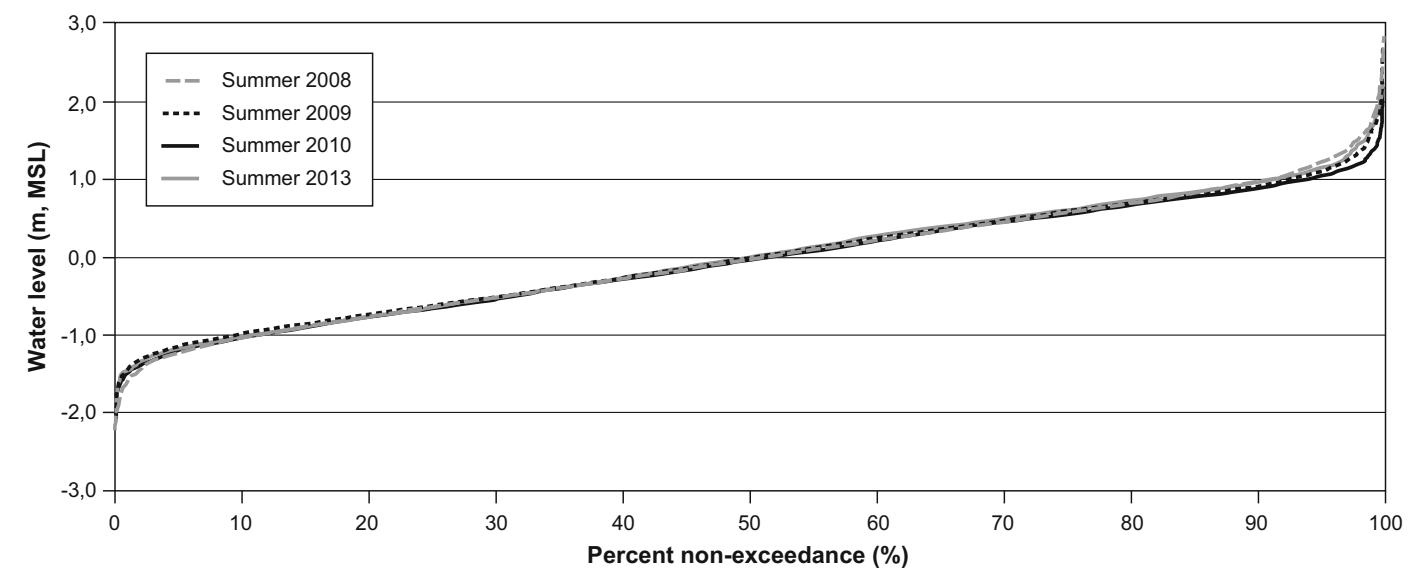

Fig. 9 Non-exceedance stage curves at Stag Rock station (RUPE0455) for ice-free conditions during 2008, 2009, 2010, and 2013

\section{Discussion}

Effects of discharge on saltwater intrusion

During 3 years of saltwater intrusion monitoring in open-water conditions, total river discharge varied by more than a factor of 2 (range from 1226 to $2971 \mathrm{~m}^{3} \mathrm{~s}^{-1}$ ). The combination of the Rupert diversion with an unusual small runoff in 2010 enabled the study of the influence of total discharge on saltwater intrusion in the Rupert Bay for a wide range of freshwater inflow conditions. Saltwater intrusion along the channels decreases as total river discharge increases. The effect of river discharge on the river plume extent is a wellknown phenomenon on the Connecticut River (Garvine 1974, 1975, 1977, 1982), on the Great Whale River (Ingram, 1981), and on the Fraser River (Cordes et al., 1980). It is also discussed on a much larger scale in Prinsenberg (1994) and Déry et al., 2005) and more specifically for diversions, where the effects of multiple river discharges in large bodies of water are studied. In this last paper, natural and anthropogenic impacts on river discharge (such as river diversions) are addressed. Déry et al. suggested that the annual upper-ocean minimum salinity observed on the Newfoundland Shelf can be explained by freshwater pulses composed of meltwater from three successive winter seasons in the river basins draining into the Hudson, James, and Ungava Bays. Moreover, they suggested that a gradual salinization of the upper ocean during summer over the period of 1966-1994 on the inner Newfoundland Shelf is in accord with a decadal trend of a diminishing intensity in the continental meltwater pulses. For the present case and for this range of total river discharge, an increase in river discharge results in a decrease of the saltwater incursion limit distance along the channels (Fig. 13).

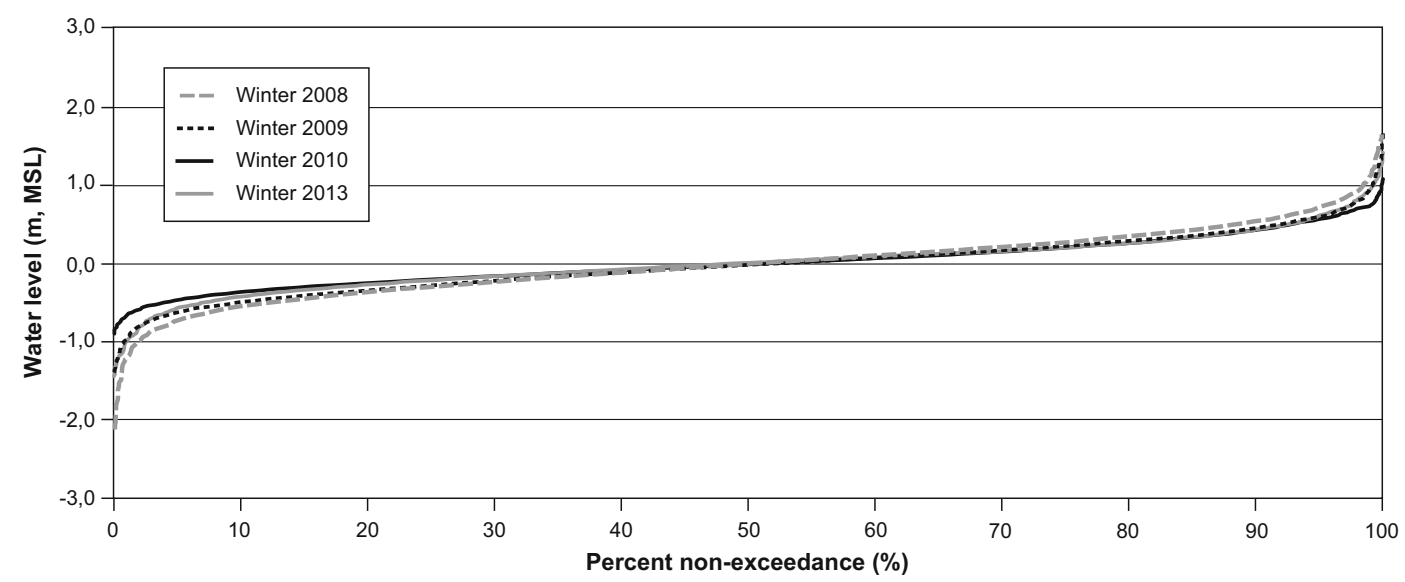

Fig. 10 Non-exceedance stage curves at Stag Rock station (RUPE0455) for ice cover conditions during 2008, 2009, 2010, and 2013 


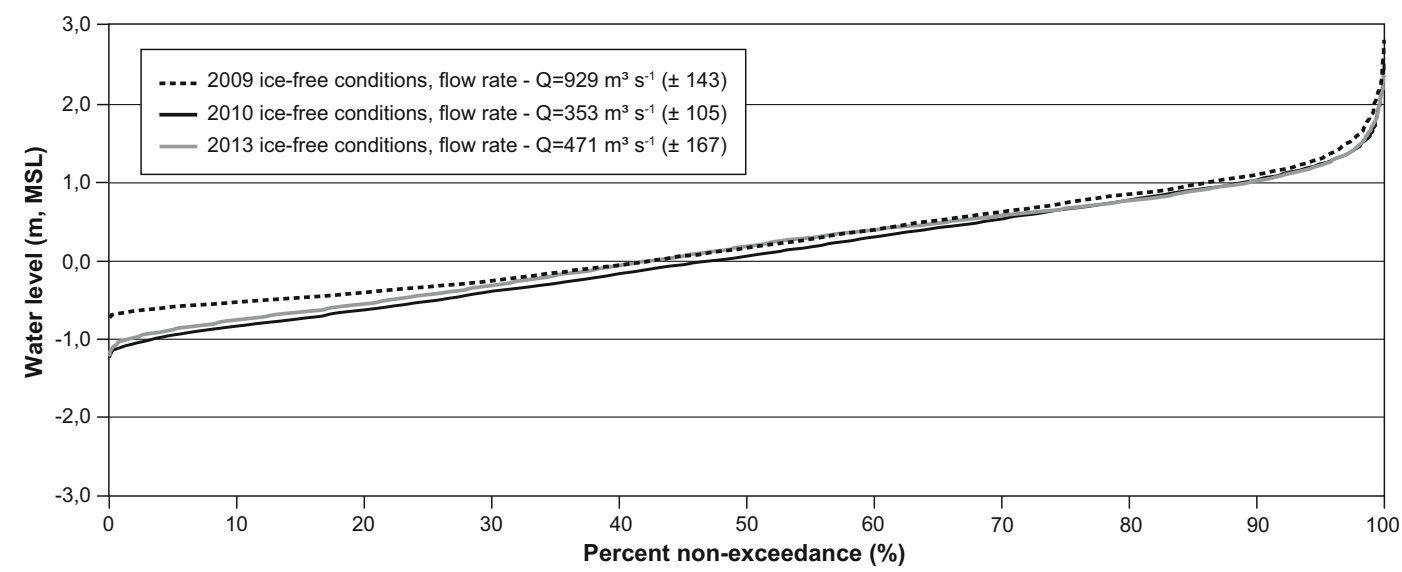

Fig. 11 Non-exceedance stage curves at station RUPE0939 for ice-free conditions during 2009, 2010, and 2013

Because of tidal flats and shallow waters, saltwater intrusions are episodic near shore, being more subject to weather conditions and wind setup as compared with the saltwater intrusion in the channels. Dupuis (2004), based on a numerical modeling, evaluated that the disruption of normal salinity incursion patterns due to storms fades after a few days. The influence of offshore winds on the along-estuary salinity gradient and residence time was observed by Geyer (1997) on Childs River. In Rupert Bay, offshore winds tend to increase the residence time of saltwater near the banks and increase saltwater intrusion in terms of surface area.

\section{Effects of ice cover on saltwater intrusion}

Under ice cover conditions, our study showed that the river's freshwater plume extends much more in the downstream direction and covers a larger surface area than in open water (Fig. 8), despite the reduced freshwater discharge during the winter. This observation is consistent with previous studies such as Freeman (1982), Ingram (1981), and Ingram and Larouche (1987a) on Great Whale River as well as Messier et al. (1986, 1989) and Ingram and Larouche (1987b) on La Grande Rivière. The larger extent of the plume is associated with the additional friction associated with the presence of the ice cover which lessens the wetted area and obstructs the incoming saltwater inflow driven by tides. It results in a flatter tidal wave amplitude signal and less energy to push the saltwater front upstream. Indeed, Prinsenberg (1986) found that tidal currents in Hudson Bay are reduced by $20 \%$ during the winter as a result of the increased frictional dissipation due to the ice cover.

A power law relationship between surface plume area and river runoff under ice cover is proposed in

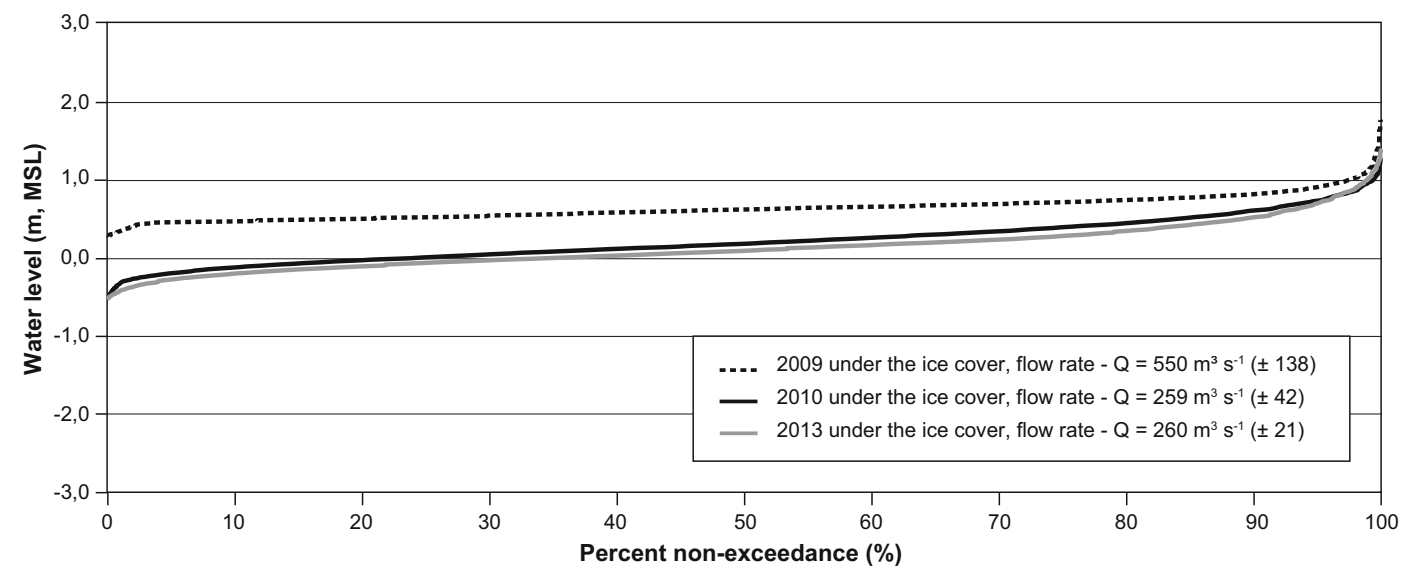

Fig. 12 Non-exceedance curves at station RUPE0939 in ice cover conditions during 2009, 2010, and 2013 

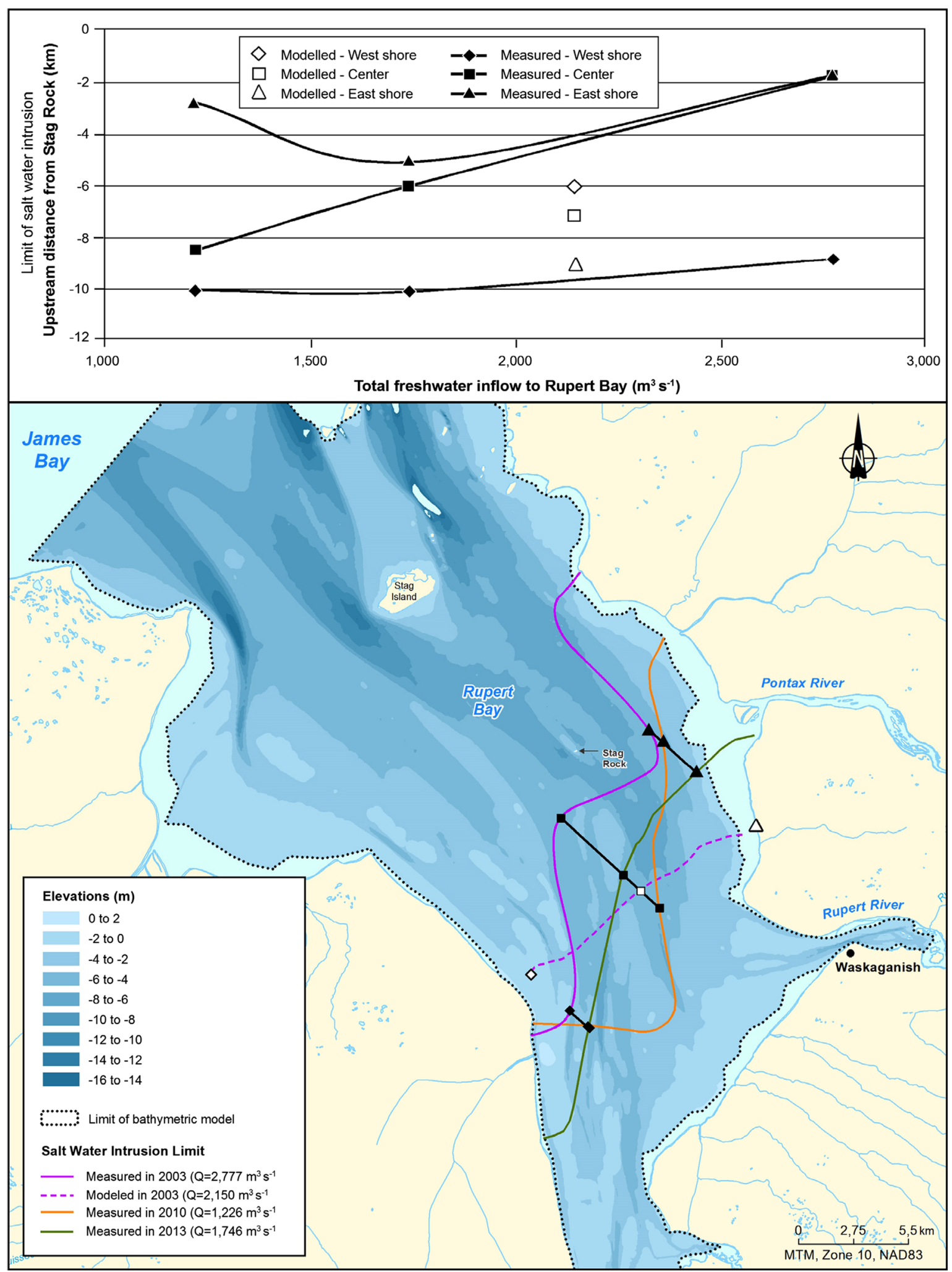

Fig. 13 Modeled and measured limits of saltwater intrusion based on discrete measurements in relation with freshwater inflow to Rupert Bay in open-water conditions 
Ingram and Larouche (1987a) and Messier and Anctil (1996). However, for the cases under study, the mouth of these rivers is located straight across linear open coasts for which the assumption of a semicircular plume area could be realistic (Leblond et al., 1996), regardless of the bathymetry, without any consideration for tidalinduced currents. On the other hand, Rupert Bay's geometry is such that it could be described as a very wide and shallow channel (mean depth less than $10 \mathrm{~m}$ ), so that the model is not likely to evaluate surface plume area properly. As discussed earlier, differences in locations and displacement of the salinity intrusion front are mainly related to weather fluctuations and the state of ice cover that prevailed during the limited field campaign time span when the tracking of the movement of the saline front was performed.

Impact assessment process

For Rupert Bay, the main changes predicted in the project environmental impact assessment were as follows (Hydro-Québec, 2004):

- a decrease in current velocities in the Rupert River upstream of Waskaganish village

- a decrease of 60 to $70 \mathrm{~cm}$ of water levels at low tide, within the upper estuary of the Rupert River, upstream of Waskaganish village

- a displacement of the maximum intrusion of saline front of $5 \mathrm{~km}$ further upstream within the Rupert Bay

- a slight shift of the freshwater flow corridors from the Nottaway, Rupert, and Broadback Rivers in Rupert Bay toward the northeast

- no noticeable variation in water levels in Rupert Bay.

Changes in velocity and water level upstream of Waskaganish village were predicted based on the expected decrease in water discharge stemming from the diversion of the river $314 \mathrm{~km}$ upstream. Although the focus of the current study was the changes in the bay area, the available data on water levels near the river's mouth are consistent with a $60-$ to $70-\mathrm{cm}$ decrease (Consortium Waska-Genivar, 2014).

The last three predictions may be evaluated based on the present study.

A comparison between numerical predictions (Fig. 13; Dupuis, 2004) and monitoring results shows that the numerical model over-predicted the displacement of the upstream limit of the saline front by about $3 \mathrm{~km}$ along the channels. These observations show the conservative nature of the model which may be explained by a conservative adjustment of the dispersiondiffusion coefficient. Furthermore, the model does not represent the asymmetry observed in the saline front as measured in situ. Asymmetry is characterized by a more pronounced intrusion of the saline front on the west shore and less intrusion on the east shore of the bay. The most likely hypothesis to explain the differences is related to the effects of the Coriolis force which was neglected in the numerical model (Consortium WaskaGenivar, 2014).

The EIA also predicted a displacement of flow corridors of Nottaway, Rupert, and Broadback Rivers in Rupert Bay. The increase in saline intrusion on the west side of the bay may be a manifestation of this displacement of freshwater flow from the Nottaway, Rupert, and Broadback Rivers.

As predicted in the EIA, the comparison of water levels measured at Stag Rock during 2008, 2009, 2010, and 2013 monitoring shows that the partial diversion of the Rupert River has no noticeable effect on water levels in Rupert Bay.

\section{Conclusion}

Rupert Bay is a particular site being a large estuary with very shallow depths which receives a large volume of freshwater inflow from three major rivers on its eastern boundary and where tidal forcing and weather conditions play a major role in water level variations.

In order to improve the knowledge of Rupert Bay hydrodynamics and to understand the impacts of diversion of one of its major tributaries on the saltwater intrusion and the limit of these zones, more than 15 studies, combining oceanographic and hydrological measurements to numerical modeling, were conducted since 1977.

After the diversion, the limit of saltwater intrusion appears to have moved upstream by 4 to $6 \mathrm{~km}$ along the main channels. Onshore, intrusion also appears to have increased, especially on the eastern shore of the bay. Under ice cover conditions, the limit of saltwater intrusion has not reached Stag Rock Island for all years of monitoring, while in open water, it went a few 
kilometers upstream. No noticeable variations in water levels in Rupert Bay were observed after the diversion.

Overall, a good agreement between numerical predictions and monitoring results is observed. Especially, the trends and order of magnitude of the changes in saltwater intrusion are confirmed by salinity and hydraulic measurements in Rupert Bay. Monitoring is also consistent with the changes predicted in the EIA which appear a posteriori conservative.

Monitoring, undertaken in 2010 and 2013 and relying exclusively on empirical data collected both in openwater and ice cover conditions, confirms the predicted trends and order of magnitude of changes anticipated by Rupert Bay EIA. This highlights the good overall performance of the impact assessment and validation process carried out for the Rupert Bay over the years, where the impact of the diversion was first predicted with an acceptable level of precision and was confirmed and refined post-diversion using only empirical measurements during 2 years of operation of the project.

Open Access This article is distributed under the terms of the Creative Commons Attribution 4.0 International License (http:// creativecommons.org/licenses/by/4.0/), which permits unrestricted use, distribution, and reproduction in any medium, provided you give appropriate credit to the original author(s) and the source, provide a link to the Creative Commons license, and indicate if changes were made.

\section{References}

Consortium Waska-Genivar. (2014). Centrales de l'Eastmain-1-A et de la Sarcelle et dérivation Rupert - Suivi de l'intrusion saline dans la baie de Rupert. Rapport d'étude 2014. Rapport présenté à Hydro-Québec Production. 91 pages et annexes.

Cordes, R. E., Pond, S., de Lange Boom, B. R., Leblond, P. H., \& Crean, P. B. (1980). Estimates of entrainment in the Fraser river plume, British Columbia. Atmosphere-Ocean, 18(1), 15-26. https://doi.org/10.1080/07055900.1980.9649074.

Déry, S. J., Stieglitz, M., Mckenna, E. C., \& Wood, E. F. (2005). Characteristics and trends of river discharge into Hudson, James, and Ungava Bays, 1964-2000. Journal of Climate, 18(14), 2540-2557. https://doi.org/10.1175/JCLI3440.1.

Dunbar, M. J. (1982). Oceanographic research in Hudson and James Bays. Naturaliste Canadien, 109(4), 677-683.

Dupuis, P. (2004). Avant-projet — Centrale de l'Eastmain-1-A et dérivation Rupert - Régime hydrodynamique de la baie de Rupert - Rapport sectoriel. In Unité conception hydraulique et géotechnique, direction Ingénierie de production. HydroQuébec: Équipement. Multiple pagination.

Dupuis, P. (2010). Baie de Rupert. Traitement de signaux de marée. Aquapraxis. Pour Hydro-Québec Équipement. 66 p. et annexes.
Environnement Illimité INC. (2011). Centrales de l'Eastmain-1-A et de la Sarcelle et dérivation Rupert. Suivi de l'intrusion saline dans la baie de Rupert et la rivière Pontax. Rapport d'analyse 2010.

Foreman, M. G. G. (1977). Manual for tidal analysis and prediction. Victoria, B.C.: Institute of Ocean Sciences.

Freeman, N. G. (1982). Measurement and modelling of freshwater plumes under an ice cover. Bayfield Laboratory Manuscript Series no. 14. Unpublish ms. Available at Department of Fisheries and Oceans, P.O. Box 5050, Burlington, Ontario L7R 4A6. 155 p.

Freeman, N. G., Roff, J. C., \& Pett, R. J. (1982). Physical, chemical, and biological features of river plumes under an ice cover in James and Hudson Bays. Naturaliste Canadien, 109(4), 745-764.

Garvine, R. W. (1974). Physical features of the Connecticut River outflow during high discharge. Journal of Geophysical Research, 79(6), 831-846. https://doi.org/10.1029/JC079 i006p00831.

Garvine, R. W. (1975). The distribution of salinity and temperature in the Connecticut River estuary. Journal of Geophysical Research, 80(9), 1176-1183. https://doi.org/10.1029/JC080 i009p01176.

Garvine, R. W. (1977). Observations of the motion field of the Connecticut River plume. Journal of Geophysical Research, 82(3), 441-454. https://doi.org/10.1029/JC082i003p00441.

Garvine, R. W. (1982). A steady state model for buoyant surface plume hydrodynamics in coastal waters. Tellus, 34, 293-306.

Genivar. (2011). Utilisation du logiciel Aquawave. Formation. Juin 2011.

Godin, G. (1972). The analysis of tides (p. 264). Toronto: University of Toronto Press.

Geyer, W. R. (1997). Influence of wind on dynamics and flushing of sallow estuaries. Estuarine, Coastal and Shelf Science, 44(6), 713-722. https://doi.org/10.1006/ecss.1996.0140.

Hayeur, G. (2001). Synthèse des connaissances environnementales acquises en milieu nordique de 1970 à 2000 (p. 110). Hydro-Québec: Montréal.

Hydro-Québec. (2004). Centrale de 1'Eastmain-1-A et dérivation Rupert - Étude d'impact sur l'environnement — Volumes 1 à 9 .

Ingram, R. G. (1981). Characteristics of the Great Whale River plume. Journal of Geophysical Research, 86(C3), 20172023. https://doi.org/10.1029/JC086iC03p02017.

Ingram, R. G. (1983). Salt entrainment and mixing processes in an under-ice river plume. In H. G. Cade, A. Edwards, \& H. Svendsen (Eds.), Coastal oceanography (pp. 551-564). New York: Plenum Press. https://doi.org/10.1007/978-1-46156648-9 31.

Ingram, R. G., \& Larouche, P. (1987a). Variability of an under-ice river plume in Hudson Bay. Journal of Geophysical Research, 92(C9), 9541-9547. https://doi.org/10.1029 /JC092iC09p09541.

Ingram, R. G., \& Larouche, P. (1987b). Changes in the under-ice characteristics of the La Grande Riviere plume due to discharge variations. Atmosphere-Ocean, 25(3), 242-250. https://doi.org/10.1080/07055900.1987.9649273.

Leblond, P. H., Lazier, J. R. \& Weaver, A. J. (1996). Can regulation of freshwater runoff in Hudson Bay affect the climate of the North Atlantic? Arctic, 49(4), 348-355. 
Lepage, S., \& Ingram, R. G. (1991). Variation of upper layer dynamics during breakup of the seasonal ice cover in Hudson Bay. Journal of Geophysical Research., 96(7), 12711-12724. https://doi.org/10.1029/91JC00454.

Messier, D., Ingram, R. G., \& Roy, D. (1986). Physical and biological modifications in response to La Grande hydroelectric complex. In I. P. Martini (Ed.), Canadian inland seas. pp. 403-424. Amsterdam: Elsevier Oceanography Series no. 44. Elsevier Science Publishers B. V.

Messier, D., Lepage, S., \& de Margerie, S. (1989). Influence du couvert de glace sur l'étendue du panache de. La Grande Rivière (baie James) Arctic, 42(3), 278-284.

Messier, D., \& Anctil, J.-F. (1996). On under-ice river plumes in James and Hudson Bays: A447-A458. In M. Leclerc et al.
(Eds.), Proceedings of the 2nd International Symposium on Habitat Hydraulics, Ecohydraulics 2000. Canada: Québec.

Prinsenberg, S. J. (1982). Present and future circulation and salinity in James Bay. Naturaliste Can., 109, 827-841.

Prinsenberg, S. J. (1986). The circulation pattern and current structure of Hudson. In E. P. Martini (Ed.), Canadian inland seas, Oceanogr. Ser. 44 pp. 187-203. New York: Elsevier.

Prinsenberg, S. J. (1994). Effects of hydro-electric projects on Hudson Bay's marine and ice environments (pp. 30). Ottawa: Canadian Arctic Resources Committee.

Rosenberg, D. M., Mccully, P., \& Pringle, C. M. (2000). Globalscale environmental effects of hydrological alterations: introduction. Bioscience, 50(9), 746-751. https://doi.org/10.1641 /0006-3568(2000)050[0746:GSEEOH]2.0.CO;2. 